\title{
KAJIAN KELAYAKAN PEMANFAATAN BIOGASDARI PENGOLAHAN AIR LIMBAH UNTUK MEMASAK
}

\author{
Pradnya Rahmani(1), Djoko M Hartono(1,2) , Haryoto Kusnoputranto(1,3) \\ (1)Program Magister Studi Ilmu Lingkungan, Program Pascasarjana,Universitas indonesia. \\ (2)Program Teknik Lingkungan, Departemen Teknik Sipil, Fakultas Teknik, Universitas Indonesia \\ (3)Departemen Kesehatan Lingkungan, Fakultas Kesehatan Masyarakat dan Program Studi Ilmu \\ Lingkungan, Program Pascasarjana, Universitas Indonesia \\ * email: pradnya.rahmani11@ui.ac.id; djokomh@eng.ui.ac.id; haryotok@ui.ac.id
}

\begin{abstract}
ABSTRAK
Penelitian ini mengkaji kelayakan teknis dan lingkungan dari pemanfaatan Biogas Instalasi Pengolahan Air Limbah (IPAL) PD PAL JAYA. IPAL PD PAL JAYA dapat menghasilkan biogas yang dapat dimanfaatkan sebagai bahan bakar untuk memasak bagi warga sekitar. Warga yang dimaksud pada penelitian ini adalah warga RT 014/ RW 006 Kelurahan Guntur, Kecamatan Setiabudi. Kajian kelayakan teknis melihat kecukupan potensi biogas untuk memenuhi kebutuhan biogas warga sekitar. Kajian lingkungan melihat signifikansi pengurangan konsumsi LPG dan minyak tanah. Hasil dari keempat kajian mendapatkan hasil yang positif sehingga pemanfaatan biogas dari IPAL PD PAL JAYA layak secara teknis dab lingkungan.
\end{abstract}

Kata Kunci: Bahan Bakar Memasak yang berkelanjutan, Biogas dari Limbah Domestik, Pemanfaatan Biogas, Pengolahan Air Limbah

\section{ABSTRACT}

This study analyze the technical and environmental feasibility of biogas utilization from PD PAL Jaya Sewage Treatment Plant (STP). The PD PAL Jaya STP can produce biogas which can be used as a cooking fuel for locals residents. The local residents which referred to this research is the resident of RT 014/006 RW Kecamatan Guntur, Kelurahan Setiabudi. The technical aspect of this research analyze the adequacy of biogas potention from PD PAL Jaya STP with the ammount of biogas that is needed by the local residents. The environmental aspect of this research analyze the significance of the LPG and kerosene consumption reduction. All of the results from these two aspects are positive. Ther efore the utilization of biogas from wastewater PD PAL Jaya technically feasible and environmentally sustainable.

Keywords: Biogas Utilization, Sewage Biogas, Sewage Treatment, Sustainable Cooking Fuel

\section{Pendahuluan}

Seiring berjalannya waktu, konsumsi minyak bumi semakin meningkat. Konsumsi minyak bumi yang semakin meningkat dipengaruhi oleh Fantazzin et al., (2011) yang menyimpulkan bahwa saat ini pengeboran minyak bumi sudah tidak dapat dilakukan lagi di daratan.

Minyak bumi digunakan untuk berbagai macam keperluan. Diantaranya

adalah untuk bahan bakar kendaraan, pembangkit listrik, dan untuk memasak. Minyak bumi yang digunakan untuk memasak lebih dikenal dengan sebutan Liquid Petroleum Gas (LPG). Seperti halnya konsumsi minyak bumi, konsumsi LPG di Indonesia semakin naik dari tahun ke tahun. Pada tahun 2000, penggunaan LPG di Indonesia sekitar 843.000 ton, lalu pada tahun 2010 
penggunaannya naik menjadi 3.689.000 ton. Kenaikan penggunaan LPG disebabkan adanya program penggantian minyak tanah menjadi LPG. Penggantian minyak tanah ke LPG tidak selamanya baik, karena persediaan LPG juga terbatas. Hal ini terlihat dari hasil produksi LPG Indonesia, pada tahun 2000 produksi LPG di Indonesia masih memenuhi kebutuhan dalam negeri, sehingga tidak perlu impor, sedangkan pada tahun 2010 diperlukan impor sampai sebanyak 1 juta ton LPG (Kementerian ESDM, 2011).

Keterbatasan persediaan LPG tidak hanya ditunjukkan dalam data. Kenyataan kelangkaan LPG di lapangan juga sudah sering kali terjadi, bahkan di DKI Jakarta. Kejadian paling baru di Jakarta terjadi pada awal bulan Mei 2012, pasokan LPG ke pengecer turun menjadi hampir setengahnya (Baehaqi dan Nasution, 2012).

Untuk menyiasati kelangkaan LPG, beberapa alternatif bahan bakar lain untuk memasak sudah mulai diperkenalkan, diantaranya adalah tungku surya dan biogas. Kedua bahan bakar alternatif ini memiliki keunggulan dan kekurangannya masing-masing. Tungku surya memiliki kendala tingkat panas yang tidak terlalu tinggi, sehingga dibutuhkan waktu yang cukup lama untuk memasak. Keunggulan dari tenaga surya adalah mudah dibawa kemanamana dan tidak membutuhkan jaringan pipa. Biogas memiliki keunggulan dapat menghasilkan panas yang hampir setara dengan LPG. Kekurangan dari biogas adalah membutuhkan reaktor biogas serta jaringan pipa dari reaktor biogas ke kompor, sehingga instalasinya cukup rumit (Bansal, et al., 2013).

Pada penelitian yang dilakukan oleh Purohit et al. (2002) di India, biogas ternyata masih kurang populer dibandingkan tungku surya. Hal ini dikarenakan masyarakat sudah memiliki kompor dengan kayu bakar yang memiliki tingkat panas tinggi. Masyarakat ini masih belum mau meninggalkan kebiasaannya menggunakan kayu bakar. Bagi mereka, tungku surya hanya digunakan untuk memasak makanan yang tidak membutuhkan panas tinggi. Bagi pengguna biogas, mereka tidak lagi menggunakan kayu bakar, karena panas dari biogas sudah cukup untuk memasak makanan harian hingga matang.

Bertolak belakang dengan penelitian Purohit et al. (2002), Gosens et al. (2013) mengemukakan bahwa di Cina, biogas justru jauh lebih populer dibanding tungku surya. Hal ini dikarenakan tingkat panas matahari di Cina tidak sebesar di India.

Mendukung pernyataan Gosens et al. (2013), Weiland (2010) mengatakan bahwa biogas akan menjadi primadona di masa mendatang. Hal ini dikarenakan biogas tersedia setiap saat, murah, dan dapat digunakan untuk berbagai macam keperluan seperti memasak, membangkitkan listrik, uap, atau hidrogen, maupun sebagai bahan bakar transportasi. Hal ini diperkuat oleh penelitian yang dilakukan oleh Koopmans (2005), yang mengatakan bahwa sebagian besar negara di asia selatan dan tenggara memiliki pasokan biomass yang cukup untuk memenuhi kebutuhan masyarakatnya.

Menurut Padmono dan Susanto (2007), tempat paling tepat untuk mengekstraksi biogas adalah tempat dengan sumber limbah organik yang terpusat. Salah satu tempat dengan limbah terpusat di Jakarta adalah Instalasi Pengolahan Air Limbah. Salah satu IPAL terbesar di Jakarta dengan kapasitas $38.880 \mathrm{~m}^{3}$ adalah PD PAL Jaya. IPAL PD PAL JAYA terletak di Kecamatan Setiabudi, Kelurahan Setiabudi, Jakarta Selatan. IPAL PD PAL JAYA menampung limbah domestik dari gedung-gedung dan rumah-rumah di kawasan Setiabudi dan Kuningan (PD PAL JAYA, 2009).

Salah satu contoh produksi biogas dari IPAL misalnya pada penelitian yang dilakukan oleh Arthur et al. (2011), dilakukan produksi biogas dari air limbah domestik empat universitas di Ghana. Dari total limbah domestik sebanyak $402.075 \mathrm{~m}^{3}$ dapat dihasilkan biogas sebesar $815.109 \mathrm{~m}^{3}$ sepanjang tahun. Berarti $1 \mathrm{~m}^{3}$ air limbah domestik dapat menghasilkan biogas sekitar $2 \mathrm{~m}^{3}$. 
Penelitian lain juga pernah dilakukan di Algeria oleh Kalloum et al. (2011), dimana dari setiap miligram Chemical Oxygen Demand (mg COD) limbah domestik yang diolah dapat dihasilkan biogas sebanyak $30 \mathrm{Nml}$ biogas.

Penelitian lain juga dilakukan oleh Le Hyaric et al. (2010), di mana lumpur IPAL diberi perlakuan pendiaman selama 4 minggu dan penambahan $6 \mathrm{~kg}$ lumpur setiap minggu sejak minggu ke-5. Hasil yang didapatkan adalah pada saat lumpur didiamkan dalam kondisi anaorobik selama 4 minggu, dihasilkan biogas sebanyak 360 liter/kg lumpur. Pada saat ada penambahan setiap minggu, produksi biogas naik menjadi 513 - 618 liter/ kg lumpur.

Agar lumpur dari limbah domestik dapat menghasilkan biogas, berdasarkan penelitian yang dilakukan oleh Igoni et al. (2008), ada beberapa hal yang harus diperhatikan. Hal-hal yang perlu diperhatikan diantaranya adalah suhu, konsentrasi hidrogen-ion, rasio carbon dan nitraogen, banyaknya limbah yang masuk, dan kelembaban.

Menurut penelitian yang dilakukan oleh Limmee-chokchai dan Chawana (2007), ada empat hambatan yang dalam penerapan penggunaan biogas untuk mengganti LPG. Hambatanhambatan tersebut adalah investasi biaya tinggi, kurangnya sumber keuangan, kurangnya informasi, dan kurangnya tenaga ahli dan tenaga terampil.

Biogas yang dihasilkan dari IPAL PD PAL JAYA saat ini masih dibiarkan terlepas ke udara. Untuk dapat memanfaatkan biogas yang dihasilkan ini perlu ada penangkapan biogas dari proses pengolahan air limbah di PD PAL JAYA. Penangkapan biogas dari sistem pengolahan air yang menggunakan Kolam Aerasi cukup sulit untuk dilakukan karena permukaannya yang terlalu luas. Untuk itu diperlukan adanya perbaikan pada sistem pengolahan air di PD PAL JAYA agar biogas yang dikeluarkan ini dapat dimanfaatkan.

Terkait mengenai pemanfaatan biogas yang ditangkap hingga saat ini, belum ada perencanaan lebih lanjut dari pihak PD PAL JAYA untuk memanfaatkan biogas. Untuk itu diperlukan kajian untuk menilai kelayakan pemanfaatan biogas dari IPAL PD PAL JAYA. Prinsip dari kajian kelayakan pemanfaatan biogas adalah sesuai secara teknis (technically feasible), menguntungkan secara ekonomi (economically profitable), diterima secara sosial (socially acceptable), dan berkelanjutan secara lingkungan (environmentally sustainable) (Ariani, 2011).

Biogas yang terbentuk dari IPAL PD PAL JAYA sangat berpotensi untuk dijadikan bahan bakar terutama untuk memasak. Penggunaan bahan bakar biogas untuk memasak dapat memberi manfaat lingkungan. Manfaat lingkungan yang diberikan adalah berkurangnya konsumsi bahan bakar fosil yang saat ini sudah semakin menipis jumlahnya.

Berdasarkan uraian di atas, permasalahan yang dapat disimpulkan adalah:

Belum ada pemanfaatan biogas dari IPAL PD PAL JAYA, padahal ada potensi biogas yang dapat dihasilkan dari IPAL PD PAL JAYA.

Berdasarkan rumusan masalah di atas dapat disusun beberapa pertanyaan:

1. Bagaimana kecukupan dari biogas yang dihasilkan IPAL PD PAL JAYA cukup untuk memenuhi kebutuhan memasak warga sekitar?

2. Bagaimana pengurangan konsumsi LPG dan minyak tanah yang dapat dicapai dengan pemanfaatan biogas dari IPAL PD PALJAYA?

\section{Metode}

Penelitian ini menggunakan pendekatan kuantitatif dengan metode prospektif. Sumber data penelitian berasal dari data lab PD PAL JAYA, kuesioner masyarakat, dan studi literatur. Untuk mendapatkan tujuan, ada beberapa aspek yang dikaji, yakni kecukupan potensi biogas untuk memasak, pengurangan konsumsi LPG dan minyak tanah, penghematan biaya memasak, dan penerimaan masyarakat.

Kecukupan potensi biogas untuk kebutuhan memasak warga sekitar dikaji dengan membandingkan 
perkiraan potensi biogas yang dapat dihasilkan dengan kebutuhan memasak warga sekitar. Adapun rumus untuk mencari potensi biogas dijabarkan pada rumus 1 dan 2 .

$$
M_{0}=\frac{B O D+2 . C O D}{3}
$$

Di mana,

Mo = Materi teroksidasi $(\mathrm{kg} / \mathrm{dt})$

$\mathrm{BOD}=\operatorname{Jumlah} \mathrm{BOD}(\mathrm{mg} / \mathrm{dt})$

$\mathrm{COD}=$ Jumlah COD $(\mathrm{mg} / \mathrm{dt})$

$\mathrm{Q}=\mathrm{Bo} . \mathrm{Mo}$

Di mana,

$\mathrm{Q}=$ Jumlah biogas yang diproduksi $\left(\mathrm{m}^{3} /\right.$ detik $)$

Bo $=$ Potensi produksi biogas (Lihat Gambar 5)

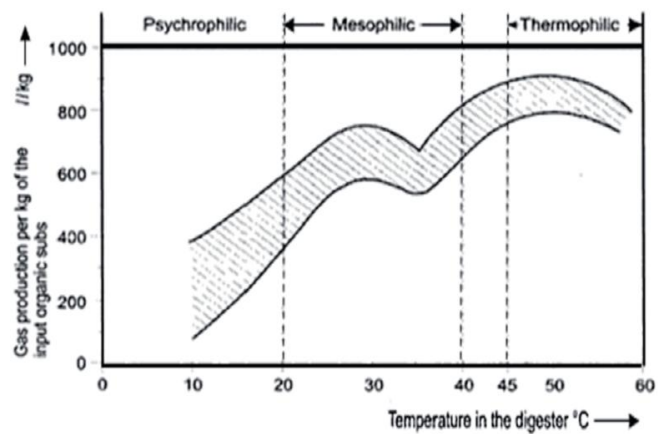

Gambar 1.

Potensi Produksi Biogas Berdasar Suhu (Bouille dan Dubois, 2004)

Kebutuhan memasak warga sekitar dicari dengan kuesioner. Dari hasil kuesioner dapat dicari kebutuhan seluruh warga. Kebutuhan LPG dan minyak tanah yang kemudian disetarakan dengan biogas untuk mendapatkan kebutuhan biogas. Rumus penyetaraan LPG dan minyak tanah dengan biogas dijabarkan pada rumus 3 dan 4.

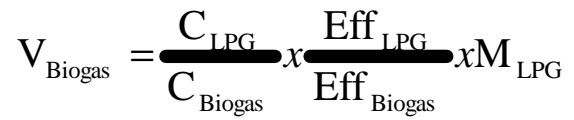

(Arthur, 2011) (3)

Di mana,

$$
\begin{array}{lll}
\mathrm{V}_{\text {biogas }}= & \text { Volume biogas yang } \\
& \text { dibutuhkan }(\mathrm{m} 3 / \text { tahun }) \\
\mathrm{C}_{\text {biogas }}= & \text { Nilai kalor biogas }(25 \mathrm{MJ} / \mathrm{m} 3 \\
& \text { biogas) } \\
\mathrm{C}_{\mathrm{LPG}}= & \text { Nilai kalor LPG (46.1 MJ/kg } \\
& \text { LPG) } \\
\text { Eff }_{\text {Biogas }}= & \text { Efisiensi kompor saat } \\
& \text { menggunakan biogas }(45 \%)
\end{array}
$$

Eff $_{\text {LPG }}=$ Efisiensi kompor saat menggunakan LPG (60\%)

$\mathrm{M}_{\mathrm{LPG}}=$ Jumlah konsumsi LPG (kg/tahun)

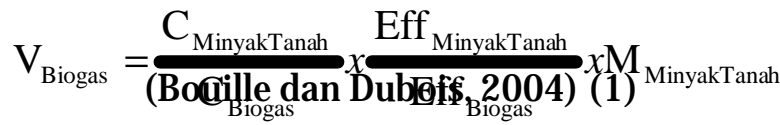

(Arthur, 2011) (4)

Di mana,

$\mathrm{V}_{\text {Biogas }}=$ Volume biogas yang

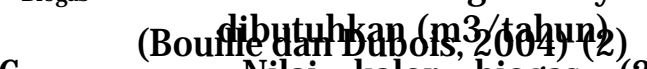

$\mathrm{C}_{\text {Biogas }} \stackrel{\text { Nilai kalor biogas }}{(25}$ $\mathrm{MJ} / \mathrm{m} 3$ )

$\mathrm{C}_{\text {MinyakTanah }}=$ Nilai kalor minyak tanah (35.1 MJ/liter minyak tanah)

Eff $_{\text {Biogas }}=$ Efisiensi kompor saat menggunakan biogas $(45 \%)$

Eff $_{\text {Minyak Tanah }}=$ Efisiensi kompor saat menggunakan minyak tanah $(43 \%)$

$\mathrm{M}_{\text {Minyak Tanah }}=$ Jumlah konsumsi minyak tanah (liter/ tahun)

Kebutuhan biogas dan potensi biogas yang telah didapatkan kemudian diproyeksikan untuk 20 tahun mendatang menggunakan rumus 5 .

$\mathrm{Y}_{\mathrm{t}}=\mathrm{a}+\mathrm{art}^{\mathrm{t}-1} \quad$ (Sugiyono, 2007) (5)

Di mana,

Yt $=$ Nilai pada tahun ke $\mathrm{t}$

$\mathrm{t}=$ Tahun proyeksi - tahun saat penelitan (tahun 2013) (misal untuk proyeksi tahun 2018 berarti $\mathrm{t}=2018$ - $2012=6$ )

$\mathrm{a}=$ Nilai awal pada saat penelitian, yaitu produksi biogas yang setara dengan LPG dan konsumsi LPG warga sekitar selama 1 tahun pada tahun 2012 .

$r=$ Rasio pertambahan nilai. Rasio yang digunakan didapat dari hasil studi literatur. Rasio kenaikan konsumsi LPG diperkirakan sekitar 7\% setiap tahunnya. Rasio penurunan konsumsi minyak tanah diperkirakan sekitar 2\% per tahun (ESDM, 2011). Rasio kenaikan produksi biogas diperkirakan sekitar 10\% setiap tahunnya karena adanya 
penambahan pelanggan PD PAL JAYA (PD PAL JAYA, 2011).

Kebutuhan biogas dan potensi biogas yang telah diproyeksikan kemudian dibandingkan. Apabila mendapatkan hasil potensi biogas di atas kebutuhan biogas maka proyek ini layak secara teknis.

Pengurangan konsumsi LPG dan minyak tanah dikaji dengan analisa Paired Sample T Test. Analisa Paired Sample T Test menggunakan SPSS. Data yang dibandingkan adalah data konsumsi LPG dan minyak tanah di DKI Jakarta tanpa penggunaan biogas dengan data konsumsi LPG dan minyak tanah di DKI Jakarta di mana ada penggunaan biogas.

Tahapan pertama dalam melakukan analisa Paired Sample T Test adalah membuat tabel data yang akan dibandingkan. Pada penelitian ini data yang akan dibandingkan adalah data konsumsi LPG dan minyak tanah di Jakarta tanpa dan dengan ada pemanfaatan biogas. Data awal yang dibutuhkan adalah data mengenai kebutuhan LPG dan minyak tanah DKI Jakarta. Berdasarkan Buku "Status Lingkungan Hidup Daerah Provinsi DKI Jakarta 2011", kebutuhan LPG dan minyak tanah pada tahun 2010 adalah 2.577.880 kiloliter/tahun atau 3,667,125.07 kg/hari dan 121.832 kiloliter/tahun atau 343,188.73 liter/ hari.

Data awal kebutuhan LPG dan minyak tanah kemudian diproyeksikan dengan rumus 10. Proyeksi kebutuhan minyak tanah menggunakan rasio penurunan sebesar $2 \%$ per tahun. Proyeksi kebutuhan LPG menggunakan rasio kenaikan sebesar 7\% per tahun.

Setelah perhitungan diproses, akan muncul data mengenai nilai Sig (2Tailed) dan t-hitung. Nilai Sig (2-Tailed) yand didapat kemudian dibandingkan dengan tingkat kesalahan yang telah ditentukan. Nilai t-hitung dibandingkan dengan nilai t-tabel yang telah ditentukan. Ada beberapa kemungkinan yang terjadi, yakni (Wagner, 2007):

1) Jika Sig (2-Tailed) > tingkat kesalahan dan t-hitung < t-tabel, maka data kedua kelompok tidak berbeda secara signifikan

2) Jika Sig (2-Tailed) $\leq$ tingkat kesalahan dan t- hitung $>$ t-tabel, maka data kedua kelompok berbeda secara signifikan

Hasil yang layak secara lingkungan adalah jika data kedua kelompok berbeda secara signifikan. Adanya perbedaan yang signifikan menandakan bahwa pemanfaatan biogas dari IPAL PD PALJAYA layak dari sisi lingkungan.

\section{Hasil dan Pembahasan}

3.1. Gambaran Umum Wilayah Penelitian

Pengolahan Air Limbah PD PAL JAYA terletak di Jalan Sultan Agung No. 1, Kelurahan Setiabudi, Kecamatan Setiabudi, Jakarta Selatan. Pengolahan Air Limbah PD PAL JAYA menempati daerah seluas $43.500 \mathrm{~m}^{2}$. Lahan seluas ini digunakan sebagai waduk yang terdiri dari Waduk Setiabudi Timur dan Waduk Setiabudi Barat. Waduk Setiabudi Barat menempati lahan seluas $26.100 \mathrm{~m}^{2}$ dan Waduk Setiabudi Timur menempati lahan seluas $17.400 \mathrm{~m}^{2}$.

Kedua waduk berfungsi sebagai pengolah air limbah yang menggunakan sistem Aerated Lagoon. Aerated Lagoon adalah sistem pengolahan air yang menggunakan kolam atau waduk serta aerator. Aerator berfungsi untuk memasok oksigen di dalam waduk. Pasokan oksigen berguna untuk mengolah air. Pada Waduk Setiabudi Barat terdapat 4 Aerator dan pada Waduk Setiabudi Timur terdapat 3 Aerator. Air limbah yang diolah di Waduk Setiabudi berasal dari beberapa rumah dan gedung yang saluran air limbahnya terhubung dengan PD PAL JAYA. Kapasitas dari masing-masing waduk adalah $78.300 \mathrm{~m}^{3}$ untuk Waduk Setiabudi Barat dan 55.680 $\mathrm{m}^{3}$ untuk Waduk Setiabudi Timur.

Selain sebagai pengolah air limbah, kedua waduk setiabudi juga memiliki fungsi sebagai pengendali banjir dengan menampung air drainase dari saluran drainase 
makro sekitar. Adanya dua fungsi ini membuat pengolahan air limbah menjadi tidak maksimal. Untuk memaksimalkan pengolahan air limbah, PD PAL JAYA telah membuat Instalasi Pengolahan Air Limbah (IPAL) baru yang terpisah dengan waduk. Ke depannya, waduk hanya berfungsi sebagai pengendali banjir dan untuk pengolahan air limbah sepenuhnya menggunakan IPAL PD PAL JAYA yang baru. Saat ini IPAL PD PAL JAYA masih dalam tahap pembangunan. Diperkirakan IPAL ini baru mulai digunakan pada tahun 2014.

Berdasarkan gambar rencana, IPAL baru PD PAL JAYA akan menggunakan sistem yang lebih kompleks dibanding Aerated Lagoon. Sistem ini terdiri dari Moving Bed Biological Reactor (MBBR), Highrate Clarifier, Pressure Filter, dan Sludge Drying Bed (SDB). Kapasitas total IPAL baru PD PAL JAYA direncanakan sebesar $20.000 \mathrm{~m} 3$.

Lumpur dari pengolahan air limbah yang terkumpul di SDB dapat mengeluarkan biogas apabila berada dalam kondisi anaerobik. Seperti penjelasan pada Bab 2, dijelaskan bahwa biogas dapat dimanfaatkan sebagai bahan bakar untuk memasak. Untuk menghasilkan biogas, SDB yang sudah ada dapat dimodifikasi sehingga membuat kondisi anaerobik.

Biogas yang terjadi nantinya akan dimanfaatkan oleh penduduk yang bermukim di sekitar PD PAL JAYA. Kawasan pemukiman yang paling dekat dengan IPAL PD PAL JAYA adalah Pemukiman RT 014/ RW 006 Kelurahan Guntur, Kecamatan Setiabudi. Kawasan ini memiliki Kepala Keluarga (KK) sebanyak 79 KK dan penduduk sebanyak 166 jiwa.

\subsection{Analisa Kecukupan Biogas}

Untuk melakukan analisa kecukupan biogas langkah pertama yang dilakukan adalah menghitung potensi biogas. Untuk menghitung potensi biogas dibutuhkan data mengenai kondisi air limbah PD PAL JAYA. Parameter yang paling penting untuk memperkirakan jumlah biogas dari air limbah adalah konsentrasi BOD, COD, ammoniak dan $\mathrm{pH}$ dalam air limbah.

\subsubsection{Potensi Biogas}

Berdasarkan data kondisi BOD dan COD, didapatkan bahwa $\mathrm{pH}$ rata-rata dari Sewer Landmark adalah 7,46 dan konsentrasi amoniak rata-ratanya adalah 1,92. Untuk Sewer D, rata-ratanya adalah 7,39 untuk nilai $\mathrm{pH}$ dan 1,88 untuk konsentrasi amoniak. Besar $\mathrm{pH}$ dan konsentrasi amoniak ini memenuhi syarat awal pemanfaatan biogas dari limbah domestik yang telah dijelaskan sebelumnya pada Bab 2 . Kedua parameter ini memenuhi syarat karena $\mathrm{pH}$ berada dalam rentang 7-8 dan amoniak masih dibawah $80 \mathrm{mg} / \mathrm{lt}$. Persyaratan lainnya adalah suhu. Berdasarkan informasi dari laboran PD PAL JAYA, suhu rata-rata dari air limbah yang masuk ke PD PAL JAYA adalah 300C. Suhu ini memenuhi syarat, di mana syarat suhu yang diperbolehkan adalah 20-25OC, 30-37 OC, 50-55 OC, dan di atas 65 OC.

Untuk menghitung jumlah biogas yang dapat dihasilkan, digunakan data konsentrasi BOD dan COD. Data BOD dan COD diolah menggunakan rumus 1 dan 2 yang telah dijelaskan pada Bab 3. Langkah pertama perhitungan jumlah biogas adalah mencari jumlah COD dan BOD per satuan waktu. Pada penelitian ini digunakan satuan miligram per detik ( $\mathrm{mg} / \mathrm{dt})$. Jumlah BOD dan COD per satuan waktu dicari dengan mengalikan konsentrasi BOD dan COD masingmasing periode dengan debit air limbah yang masuk ke IPAL PD PAL JAYA. Menurut pemantauan yang dilakukan oleh laboran PD PAL JAYA, debit rata-rata air limbah yang masuk melalui Sewer D adalah 0,5 liter/ detik. Untuk Sewer Landmark, 
debit rata-rata air limbah yang masuk adalah 42 liter/ detik.

Langkah berikutnya adalah mencari jumlah materi yang dapat teroksidasi (Mo) menggunakan rumus 1 dengan memasukkan data jumlah BOD dan COD per satuan waktu dari masing-masing waktu pemantauan. Data jumlah Mo kemudian dikalikan dengan potensi produksi biogas, sesuai rumus 2 . Berdasarkan Gambar 5 dan suhu rata-rata air limbah di IPAL PD PAL JAYA, yakni $30^{\circ} \mathrm{C}$, didapatkan potensi produksi biogas sebesar 500 liter/ kg.

Berdasarkan hasil perhitungan potensi biogas, didapatkan air limbah IPAL PD PAL JAYA dapat menghasilkan biogas dari 2,46 liter/detik hingga 7,51 liter/ detik jika berada pada kondisi anorganik. Secara rata-rata, air limbah IPAL PD PAL JAYA dapat menghasilkan biogas hingga 5,02 liter/detik atau setara dengan 144,65 m³/ hari.

3.2.2. Kebutuhan LPG dan Minyak Tanah Masyarakat RT 014/RW006 Kelurahan Guntur, Kecamatan Setiabudi ada yang menggunakan LPG dan minyak tanah sebagai bahan bakar untuk memasak. Pengumpulan data awal dilakukan dengan wawancara menggunakan quesioner. Total ada 31 responden yang diwawancara. Berdasarkan hasil wawancara, ada 4 responden atau $13 \%$ dari total responden yang menggunakan minyak tanah. Untuk pengguna LPG ada 27 orang atau sekitar 87\%. Proporsi ini digunakan untuk mencari proporsi pengguna LPG dan minyak tanah secara keseluruhan dengan dikalikan 79.

Berdasarkan perhitungan, didapatkan perkiraan bahwa jumlah pengguna minyak tanah ada 10 keluarga dan pengguna LPG ada 69 keluarga. Berdasarkan hasil quesioner, konsumsi LPG rata-rata di RT 014 RW006 Kelurahan Guntur, Kecamatan Setiabudi adalah sekitar 0,47 kg/ hari/ rumah. Untuk minyak tanah, konsumsi rata-ratanya sekitar $\quad 0,17$

liter/ hari/ rumah.

Berdasarkan jumlah konsumsi rata-rata dan jumlah pengguna LPG dan minyak tanah, dapat dicari konsumsi seluruh warga RT 014/ RW006 Kelurahan Guntur, Kecamatan Setiabudi untuk LPG dan Minyak Tanah setiap harinya. Jumlah konsumsi seluruh warga dicari dengan perkalian antara rata-rata dan jumlah pengguna LPG dan minyak tanah. Berdasarkan perhitungan didapatkan hasil total konsumsi LPG seluruh warga RT 014/ RW006 Kelurahan Guntur, Kecamatan Setiabudi adalah 32,43 kg/hari. Untuk minyak tanah, total konsumsinya adalah 1,7 liter / hari.

\subsubsection{Kecukupan Biogas}

Analisa kecukupan biogas menghitung konsumsi minyak tanah dan LPG yang dapat dikurangi dengan adanya pemanfaatan biogas selama 20 tahun. Berdasarkan hasil perhitungan kebutuhan LPG pada subab 4.3, rata-rata jumlah LPG yang dibutuhkan seluruh warga per harinya adalah 15,1 kg LPG. Untuk minyak tanah, rata-rata jumlah minyak tanah yang dibutuhkan warga setiap harinya adalah 0,6 liter. Rata-rata ini akan digunakan sebagai data pada tahun pertama. Data tahun pertama akan diproyeksikan untuk 20 tahun mendatang. Proyeksi dihitung menggunakan rumus 5 dengan rasio $7 \%$.

Proyeksi dari kebutuhan minyak tanah dan LPG kemudian disetarakan dengan kebutuhan biogas. Kesetaraan kebutuhan LPG dengan biogas dihitung menggunakan rumus 3 dan kesetaraan kebutuhan minyak tanah dengan biogas dihitung menggunakan rumus 4 .

Setelah disetarakan akan didapatkan total kebutuhan biogas dari pengguna LPG dan pengguna minyak tanah. Proyeksi total kebutuhan biogas selanjutnya akan 
dibandingkan dengan proyeksi potensi biogas. Perbandingan ini dilakukan untuk mendapatkan informasi mengenai cukup tidaknya potensi biogas dalam memenuhi kebutuhan bahan bakar warga. Data awal potensi biogas adalah 144,65 $\mathrm{m}^{3} /$ hari. Perhitungan proyeksi potensi biogas juga dilakukan menggunakan rumus 5 .

Berdasarkan analisa, didapatkan hasil bahwa potensi biogas jauh melebihi kebutuhan biogas dengan selisih 62,63 m³ - 663,06 m³ . Selain itu terlihat pula dari tahun ke tahun potensi biogas semakin jauh melebihi kebutuhan biogas. Hal ini menandakan bahwa potensi biogas dari IPAL PD PAL JAYA cukup untuk memenuhi kebutuhan biogas seluruh warga. Adanya selisih yang tinggi antara potensi biogas dengan kebutuhan biogas bukan menjadi masalah. Hal ini dikarenakan adanya kemungkinan kebocoran pada pipa, sehingga tidak seluruh biogas yang terproduksi dapat disalurkan ke warga. Bahkan jauh lebih baik jika potensi biogas melebihi kebutuhan biogas dibandingkan jika potensi biogas sama dengan kebutuhan biogas.

3.3. Analisa Pengurangan Konsumsi LPG dan Minyak Tanah

Analisa pengurangan konsumsi LPG dan minyak tanah dilakukan dengan cara analisa Paired Sample T Test. Langkah pertama adalah menetapkan tingkat kesalahan dan degree of freedom (df). Tingkat kesalahan ditetapkan sebesar $5 \%$. Nilai df pada berdasarkan data yang dibandingkan adalah 20. Nilai df dan tingkat kesalahan digunakan untuk menentukan t-tabel. Berdasarkan nilai $\mathrm{df}=20$ dan tingkat kesalahan $=$ 0,05 didapatkan nilai t-tabel sebesar 1,725 .

Langkah selanjutnya adalah melakukan analisa Paired Sample T Test dengan SPSS. Hasil yang didapatkan pada perbandingan konsumsi LPG adalah nilai t-hitung sebesar 11,098 dan nilai Sig (2Tailed) sebesar 0,000. Hasil yang didapatkan untuk perbandingan konsumsi minyak tanah adalah thitung sebesar 36,614 dan nilai Sig (2-Tailed) sebesar 0,000.

Bila dibandingkan dengan ttabel yakni 1,725, nilai t-hitung baik dari konsumsi LPG maupun konsumsi minyak tanah melebihi ttabel. Bila dibandingkan dengan tingkat kesalahan, yakni 0,05, nilai Sig (2-Tailed) baik dari konsumsi LPG maupun konsumsi minyak tanah dibawah 0,05 . Hal ini berarti bahwa perbedaan konsumsi LPG dan minyak tanah saat tidak ada pemanfaatan biogas dengan ada pemanfaatan biogas cukup signifikan. Adanya signifikansi berarti bahwa proyek ini layak secara lingkungan.

\section{Kesimpulan}

Kesimpulan berdasarkan pembahasan pada Bab 4 adalah sebagai berikut:

1. Potensi biogas dari IPAL PD PAL Jaya cukup untuk memenuhi kebutuhan memasak warga sekitar, sehingga layak secara teknis.

2. Pemanfaatan biogas dari IPAL PD PAL JAYA dapat mengurangi konsumsi LPG dan Minyak Tanah di DKI Jakarta secara signifikan, sehingga layak secara lingkungan.

\section{Daftar Pustaka}

Andrews, P. 2008. "Energy Scarcity, Oil Depletion, and Environmental Accountability - Balancing Priorities in Times of Uncertainty". Enviromation, 51.417-422.

Ariani, E. 2011. "Faktor Keberhasilan Pengembangan Biogas di Permukiman Transmigrasi Sungai Rambutan SP .1". Jurnal Ketransmigrasian, 28. 34 - 44.

Arthur, R., Baidoo, M. F., BrewHammond, A., dan Bensah, E. C. 2011. "Biogas generation from sewage in four public universities in Ghana: A solution to potential health risk". 
Biomass and Bioenergy, 35. 30863093.

Baehaqi, A. dan Nasution, T. 012. LPG 3 KG di Jakarta Langka, Harga Naik. http:// www.indosiar.com/ fokus/lpg -3-kg-di-jakarta-langka-harganaik 95902.html, 3 Juni 2012, pk. $20.4 \overline{9}$ WIB.

Bansal, M., R.P. Saini, dan D.K. Khatod. 2013. Development of cooking sector in rural areas in India - A review. Renewable and Sustainable Energy Reviews, 17.44-53.

Bouille, E., dan Dubois, V. 2004. Traitement, épuration et valorisation des effluents d'une fromagerie. http:// hmf.enseeiht.fr/travaux/CD0 405/ beiere/4/ html/ binome3/ dim i nst.htm, 5 Juni 2012, 19.01 WIB.

Gosens, J., Y. Lu, G. He, B. Bluemling, dan T.A.M.Beckers. 2013. "Sustainability effects of household-scale biogas in rural China". Energy Policy, 54. 273287.

Fantazzini, D., M. Höök, dan A. Angelantoni. 2011. "Global oil risks in the early 21st century". Energy Policy, 39. 7865-7873.

Igoni, A.H., M.J. Ayotamuno, C.L. Eze, S.O.T. Ogaji, dan S.D. Probert. 2008. "Designs of anaerobic digesters for roducing biogas from municipal solid-waste". Applied Energy, 85. 430-438.

Kalloum, S., H. Bouabdessalem, A. Touzi, A. Iddou, dan M. S. Ouali. 2011. "Biogas production from the sludge of the municipal wastewater treatment plant of Adrar city (Southwest Algeria)". Biomass and Bioenergy, 35. 2554-2560.

Kementrian ESDM (Energi dan Sumber Daya Mineral). 2011. Handbook of Energy \& Economic Statistics of Indonesia.

http://prokum.esdm.go.id/

Publikasi/ Handbook\%20of\% 20Ener gy\%20\&\%20Economic\%20Statistics \%20of\%20Indonesia\% 20/ Handbook \%202011.pdf, 27 Mei 2012, pk. 20.45 WIB.

Koopmans, A. . 2005. "Biomass energy demand and supply for South and South-East Asia--assessing the resource base". Biomass and Bioenergy, 28. 133-150.

Le Hyaric, R., J.-P. Canler, B. Barillon, P. Naquin and R. Gourdon (2010). Pilotscale anaerobic digestion of screenings from wastewater treatment plants. Bioresource Technology, 101.9006-9011.

Limmee-chokchai, B. and S. Chawana. 2007. "Sustainable energy development strategies in the rural Thailand: The case of the improved cooking stove and the small biogas digester". Renewable and Sustainable Energy Reviews, 11.818-837.

Padmono, D. dan J.P. Susanto. 2007. "Biogas sebagai energi alternatif antara mitos dan fakta ilmiah". Jurnal Teknik Lingkungan, 8. 34-42.

Purohit, P., A. Kumar, S. Rana, dan T.C. Kandpal (2002). "Using Renewable Energy Technologies for Domestic Cooking in India: A Methodology for Potential Estimation". Renewable Energy, 26. 235-246.

Supranto, J. 1992. Teknik Sampling untuk Survei dan Eksperimen. PT. Rineka Cipta, Jakarta.

Weiland, P. 2010. "Biogas production: current state and perspectives". Applied Microbiology Biotechnology, 85. 849-860. 